\title{
PENGARUH KECERDASAN SPIRITUAL, KECERDASAN EMOSIONAL, DAMPAK NEGATIF JEJARING SOSIAL DAN KEMAMPUAN BERPIKIR DIVERGEN TERHADAP HASIL BELAJAR MATEMATIKA SISWA
}

\author{
Erwin Nurdiansyah \\ Pendidikan Matematika, Universitas Negeri Makassar \\ Email: erwin88rahman@yahoo.co.id
}

\begin{abstract}
This study aims to describe and how much influence the spiritual intelligence, emotional intelligence to the learning outcomes of mathematics either directly or indirectly through the negative impact of social networking, and divergent thinking skills students learn. This type of research is ex-post facto nature of causality. This study population is students of class X SMA Se-District of Bontotiro Bulukumba the school year 2014/2015 as many as 765 with a sample size of 175. Engineering samples is done by using proportional stratified random sampling. The instrument used in this study were (1) Methods documentation for learning outcomes, (2) Scale spiritual intelligence, (3) Scale of emotional intelligence, (4) The scale of the negative impact of social networking, (5) Test divergent thinking skills. Data were analyzed with descriptive and inferential statistical methods SEM (Structural Equation Modeling). The results showed that: (1) Most of the students have spiritual intelligence is in the category of high emotional intelligence are in the high category, the negative impact of social networking are in the low category, divergent thinking skills are in high category and yield learning mathematics are in the high category; (2) Directly spiritual intelligence positive and significant effect on the results of students' mathematics learning, indirectly positive effect but not significant to the results of students' mathematics learning through the negative impact of social networking and indirect positive and significant impact on the results of students' mathematics learning through capability divergent thinking. (3) Directly emotional intelligence positive and significant effect on the results of students' mathematics learning, indirectly positive effect but not significant to the results of students' mathematics learning through the negative impact of social networking and indirect positive and significant impact on the results of students' mathematics learning through capability divergent thinking.
\end{abstract}

Keywords: spiritual intelligence, emotional intelligence, the negative impact of social networking, keamampuan divergent thinking and mathematics learning outcomes

\begin{abstract}
ABSTRAK
Penelitian ini bertujuan untuk mengetahui gambaran dan seberapa besar pengaruh kecerdasan spiritual, kecerdasan emosional terhadap hasil belajar matematika baik secara langsung maupun tidak langsung melalui dampak negatif jejaring sosial, dan kemampuan berpikir divergen belajar siswa. Jenis penelitian ini adalah ex-post facto yang bersifat kausalitas. Populasi penelitian ini adalah siswa kelas X SMA Negeri Se-Kecamatan Bontotiro Kabupaten Bulukumba tahun pelajaran 2014/2015 sebanyak 765 dengan ukuran sampel 175. Teknik sampel dilakukan dengan menggunakan proporsional stratified random sampling. Instrumen yang digunakan dalam penelitian ini adalah (1) Metode dokumentasi untuk hasil belajar, (2) Skala kecerdasan spiritual, (3) Skala kecerdasan emosional, (4) Skala dampak negatif jejaring sosial, (5) Tes kemampuan berpikir divergen. Data dianalisis dengan statistika deskriftif dan inferensial metode SEM (Structural Equation Modeling). Hasil penelitian menunjukkan bahwa: (1) Sebagian besar siswa memiliki kecerdasan spiritual berada dalam kategori tinggi, kecerdasan emosional berada dalam kategori tinggi, dampak negatif jejaring sosial berada dalam kategori rendah, kemampuan berpikir divergen berada dalam kategori tinggi dan hasil belajar matematika berada dalam kategori tinggi; (2) Secara langsung kecerdasan spiritual berpengaruh positif dan signifikan terhadap hasil belajar matematika siswa, secara tidak langsung berpengaruh positif namun tidak signifikan terhadap hasil belajar matematika siswa melalui dampak negatif jejaring sosial dan secara tidak langsung berpengaruh positif dan signifikan terhadap hasil belajar matematika siswa melalui kemampuan berpikir divergen. (3) Secara langsung kecerdasan
\end{abstract}


emosional berpengaruh positif dan signifikan terhadap hasil belajar matematika siswa, secara tidak langsung berpengaruh positif namun tidak signifikan terhadap hasil belajar matematika siswa melalui dampak negatif jejaring sosial dan secara tidak langsung berpengaruh positif dan signifikan terhadap hasil belajar matematika siswa melalui kemampuan berpikir divergen.

Kata Kunci : Kecerdasan spiritual, kecerdasan emosional, dampak negatif jejaring sosial, keamampuan berpikir divergen dan hasil belajar matematika

\section{PENDAHULUAN}

Sistem pembelajaran matematika kita selama ini masih mementingkan aspek kognitif yaitu aspek yang menekankan transformasi informasi faktual dan pengembangan penalaran. Sedangkan aspek afektif seperti kecerdasan spiritual dan kecerdasan emosional nampaknya masih ditelantarkan. Mulai dari tingkat sekolah dasar sampai bangku kuliah, jarang sekali dijumpai pendidikan tentang kecerdasan emosi yang menanamkan kecerdasan spiritual, integritas, kejujuran, komitmen, kreatifitas, kemandirian, penguasaan diri, kebijaksanaan, keadilan, dan prinsip kepercayaan. Sehingga hal tersebut menghasilkan dampak buruk bagi ketahanan mental peserta didik dalam meningkatkan hasil belajarnya, sehingga kita dapat menjumpai di sekolah-sekolah yang siswanya cepat merasa jenuh, bosan bahkan bolos ketika pelajaran matematika dimulai, bersungguh-sungguh belajar hanya ketika mendekati ujian, demikian juga merebaknya kecurangan disetiap ujian sekolah.

Harus diakui bahwa kekuatan yang mendorong kemajuan dalam dunia usaha abad ke-20 adalah Kecerdasan Intelektual (IQ), tetapi berdasarkan bukti-bukti yang mungkin banyak dipenghujung abad ke- 21 yang akan lebih berperan adalah Kecerdasan Emosional (EQ). Fakta membuktikan bahwa orang-orang yang memiliki Kecerdasan Intelektual (IQ) yang tinggi kadang tidak lebih sukses daripada orang yang memiliki Kecerdasan Intelektual (IQ) yang rendah tetapi memiliki Kecerdasan Emosional yang tinggi.

Ada asumsi yang menyatakan bahwa untuk mencapai keberhasilan di dalam studi diperlukan taraf Intelegensi (IQ) yang tinggi karena Kecerdasan Intelektual (IQ) yang tinggi sama dengan pandai dan dianalogikan dengan berhasil di sekolah. Daniel Goleman (2007) dalam bukunya "Emosional Intelegensi" mengemukakan bahwa keberhasilan seseorang dalam hidupnya $20 \%$ ditentukan oleh
Kecerdasan Intelektual (IQ) dan $80 \%$ di isi oleh faktor-faktor lain seperti kecerdasan emosional dan kecerdasan spiritual.

Faktor pertama adalah kecerdasan emosional merupakan salah satu faktor yang berasal dari dalam diri individu dianggap penting, karena kepribadian seseorang dipengaruhi oleh emosi-emosi yang dialaminya selama manusia tumbuh dan berkembang. Seseorang yang tidak mampu mengontrol dan mengembangkan emosinya ia akan menemui kesulitan untuk mengatasi masalah-masalah yang dihadapinya baik masalah yang berhubungan dengan pembelajaran, pekerjaan, maupun hal-hal lainnya.

Kecerdasan Emosional (EQ) dan bentuk kecerdasan lainnya sebenarnya saling melengkapi dan saling menyempurnakan. Emosi dapat membangun kreatifitas, kolaborasi, inisiatif, dan transformasi sedangkan penalaran logis berfungsi mengatasi dorongan-dorongan yang keliru serta menyelaraskan tujuan, proses, dan teknologi dengan manusiawi.

Faktor kedua yaitu kecerdasan spiritual atau spiritual quotient (SQ) adalah kecerdasan yang berperan sebagai landasan yang diperlukan untuk memfungsikan IQ dan EQ secara efektif. Oleh karena itu, kecerdasan spiritual juga dikatakan sebagai kecerdasan tertinggi dalam diri kita. Kecerdasan spiritual memungkinkan peserta didik menjadi kreatif, kemampuan membudayakan, memberi rasa moral, dan memberikan makna positif. Kecerdasan spiritual mengintegrasikan semua kecerdasan kita. Kecerdasan spiritual menjadikan kita makhluk yang benar-benar utuh secara intelektual, emosional dan spiritual.

Faktor ketiga adalah dampak negatif jejaring sosial. Pengaruh negatif dari jejaring sosial adalah bagi siswa/pelajar maka kecerdasan spiritual dan hasil belajar siswa dapat menurun. hasil belajar siswa menurun akibat terlalu sering membuka situs jejaring sosial di internet. Hal ini mungkin karena kecerdasan spiritual belajar siswa tersebut juga menjadi berkurang karena 
lebih mementingkan jejaring sosialnya daripada hasil belajarnya sendiri. Salah satu dampak negatif yang ditimbulkan jejaring sosial berdasarkan teori diatas adalah prokrastinasi atau penundaan pekerjaan yang diakibatkan oleh banyaknya waktu yang di habiskan untuk situs jejaring sosial yang merupakan tempat mencari kesenangan dan hiburan sehingga dapat berdampak bagi kehidupan mereka, baik dari segi minat belajar, hasil, bersosialisasi dengan lingkungan, kepekaan sosial maupun perilakunya.

Istilah kecerdasan emosional pertama kali dilontarkan pada tahun 1990 oleh psikolog Peter Salovey dari Harvard Univercity "New Hampshire" untuk menerangkan kualitaskualitas emosional yang tampaknya penting bagi keberhasilan.

Salovey (Sawitri, 2004), mendefenisikan kecerdasan emosional atau yang disebut EI sebagai himpunan bagian dari kecerdasan emosional yang melibatkan kemampuan memantau perasaan sosial yang melibatkan kemampuan pada orang lain, memilah-milah semuanya dan menggunakan informasi ini untuk membimbing pemikiran dan tindakan.

Lebih lanjut, Salovey \& Grewal (Sawitri, 2004), mengemukakan bahwa kecerdasan emosional, suatu kemampuan mengidentifikasi emosi yang dialami oleh diri sendiri dan orang lain dengan akurat, kemampuan mengekspresikan emosi dengan tepat, dan kemampuan mengatur emosi pada diri sendiri dan orang lain. Orang-orang yang memiliki kecerdasan emosional yang tinggi mampu menggunakan emosi mereka untuk meningkatkan kecerdasan spiritual mereka, menstimulus pemikiran yang kreatif, dan mengembangkan empati terhadap orang lain. Orang-orang yang memiliki kecerdasan emosional yang kurang baik akan mengalami kesulitan dalam mengidentifikasi emosi pada diri mereka sendiri.

Sebuah model pelopor lain tentang kecerdasan emosional diajukan oleh Bar-On pada tahun 1992 seorang ahli psikologi Israel, yang mendefenisikan kecerdasan emosional sebagai serangkaian kemampuan pribadi, emosi dan sosial yang mempengaruhi kemampuan seseorang untuk berhasil dalam mengatasi tuntutan dan tekanan lingkungan (Goleman, 2007).
Kecerdasan ini dinamakan oleh Garner sebagai kecerdasan pribadi yang oleh Daniel Goleman disebut sebagai kecerdasan emosional. Dalam rumusan lain Garner menyatakan bahwa inti kecerdasan antar pribadi itu mencakup kemampuan untuk membedakan dan menanggapi dengan tepat suasana hati, temprament, kecerdasan spiritual dan hasrat orang lain. Dalam kecerdasan antar pribadi yang merupakan kunci menuju pengetahuan diri, ia mencamtumkan "akses menuju perasaaanperasaan diri seseorang dan kemampuan untuk membedakan perasaan-perasaan tersebut dan memanfaatkannya untuk menuntun tingkah laku". (Goleman, 2007)

Menurut Goleman (2007) kecerdasan emosional adalah kemampuan seseorang mengatur kehidupan emosinya dengan intelegensi (to manage our emotional lift with intelligence); menjaga keselarasan emosi dan pengungkapannya (the appropriateness of emotion and its expression) melalui keterampilan kesadaran diri, pengendalian diri, kecerdasan spiritual diri, empati dan keterampilan sosial atau dengan kata lain Goleman juga menyamakan kecerdasan emosional adalah kemampuan seseorang untuk mengenali emosi diri, mengelolah emosi, memotivasi diri sendiri, mengenali emosi orang lain (empati) dan kemampuan untuk membina hubungan (kerjasama) dengan orang lain.

Dalam penelitian ini yang dimaksud dengan kecerdasan emosional adalah kemampuan siswa mengenali emosi diri, memotivasi diri sendiri, mengenali emosi orang lain (empati) dan kemampuan untuk membina hubungan (kerjasama) dengan orang lain dalam mengatasi tuntutan dan tekanan lingkungan.

Dalam bentuk kata sifat, spiritual mengandung arti "yang berhubungan dengan yang suci atau yang berhubungan dengan fenomena atau makhluk supernatural". Dalam bahasa Arab, istilah yang digunakan untuk spiritual adalah ruhaniyyah yang diambil dari kata ruh. Oleh sebab itu, tanpa spiritual dalam diri seseorang organisme akan mati secara jasadiah ataupun kejiwaan, (Sanerya, 2009)

Zohar dan Marshall (Saenarya, 2009) mengemukakan bahwa kecerdasan spiritual adalah kecerdasan untuk memecahkan persoalan makna dan nilai, yaitu kecerdasan untuk menempatkan perilaku dan hidup dalam konteks makna yang lebih luas dan kaya, kecerdasan 
untuk menilai bahwa tindakan atau jalan hidup seseorang lebih bermakna dibandingkan yang lain. Dapat dikatakan didalam kecerdasan spiritual inilah terdapat fitrah manusia sebenarnya.

Sinetar (Lisda, 2012) mendefinisikan kecerdasan spiritual sebagai pikiran yang mendapat inspirasi, dorongan, efektivitas yang terinspirasi, dan penghayatan ketuhanan yang semua manusia menjadi bagian di dalamnya.

Kecerdasan spiritual (SQ) merupakan temuan terkini secara ilmiah oleh ahli saraf VS. Ramachandran dan timnya dari California University, yang menemukan eksistensi god spot dalam otak manusia sebagai pusat spiritual terletak di bagian depan otak, dimana fungsi otak itu akan terus mencari untuk apa saya dilahirkan, untuk apa saya hidup, dan siapa saya sebenarnya. Lebih lanjut bukti kedua dalam riset ahli saraf Austria, Wolf Singer, (Ginanjar, 2007) menunjukkan ada proses saraf dalam otak manusia yang terkonsentrasi pada usaha untuk menyatukan serta memberi makna dalam pengalaman hidup kita. Suatu jaringan saraf yang secara literal "mengikat" pengalaman kita secara bersama untuk hidup lebih bermakna.

Menurut Ginanjar (2007) "kecerdasan spiritual merupakan kecerdasan tertinggi kita". Kecerdasan spiritual adalah kemampuan untuk memberi makna ibadah serta mampu mensinergikan kecerdasan intelektual (IQ), kecerdasan emosional (EQ), dan kecerdasan spiritual (SQ) secara komprehensif kepada setiap perilaku dan kegiatan, melalui langkah-langkah dan pemikiran tauhid (integralistik), serta berpikir "hanya karena Allah". Kecerdasan spiritual yang tinggi dapat membantu manusia mencapai kegemilangan hidup. Maka, untuk mendapatkan dimensi kecerdasan spiritual perlu dikaji dari sumber Islam.

Harjani Hefni (2008) menyatakan makna kecerdasan spiritual adalah kemampuan mendengarkan suara hati untuk cerdas berhubungan dengan Tuhan YME dan sesama dalam memberikan yang terbaik dan bermanfaat. Dengan demikian kecerdasan spiritual adalah kecerdasan jiwa dalam memaknai hidup yang dapat membantu seseorang dapat membangun dirinya untuk tumbuh, berkembang dan seimbang.

Dari beberapa pendapat tentang pengertian kecerdasan spiritual di atas, dapat disimpulkan bahwa kecerdasan spiritual adalah kemampuan untuk meberi makna ibadah terhadap setiap perilaku dan kegiatan melalui langkah-langkah dan pemikiran yang bersifat fitrah, menuju manusia yang seutuhnya dan memiliki pola pemikiran luas, serta berprinsip hanya karena Allah.

Menurut Briyan (2013) mendefinisikan jejaring sosial adalah struktur sosial yang berasal dari individu-individu dan organisasi yang diikat oleh satu atau lebih tipe relasi spesifik seperti nilai, visi, ide, teman, keturunan, kesamaan hobi, kesamaan sifat, dll.

Boyn dan Ellison (Dea, 2013) mengemukakan bahwa jejaring sosial merupakan berbasis web yang memingkinkan individu untuk mengembangkan profil umum atau semi umum melalui system terikat, menunjukkan daftar pengguna lainnya dengan siapa seseorang berhubungan, dan melihat daftar hubungan mereka dan lainnya yang ada dalam sistem.

Disebut jejaring karena kemampuannya untuk saling terhubung dengan cepat antara satu domain komunitas dengan komunitas lainnya. Misalnya, kalau kita gunakan tools status di Plurk.com, maka status kita dapat didistribusikan ke facebook, tumblr, twitter, dan multiply. Bahkan ada yang seolah-olah menjadi konsolidator semua domain komunitas sehingga fungsinya lebih praktis.

Menurut Dea (2013) jejaring sosial atau sosial networking adalah sebuah bentuk layanan internet yang ditujukan sebagai komunitas online bagi orang yang memiliki kesamaan aktivitas, ketertarikan pada bidang tertentu, atau kesamaan latar balakang tertentu.

Teknologi merupakan hal mubah (boleh) yang hukumnya akan menjadi halal jika dipergunakan untuk hal-hal positif dan bermanfaat namun bisa pula menjadi haram ketika teknologi tersebut dipergunakan sebagai media dalam melakukan tindakan yang melanggar aturan Islam. Maka dari itu bagi para orang tua, guru dan para pendidik generasi menjadi sangat urgen dalam memberikan pendidikan terhadap efek negatif internet terutama situs jejaring sosial yang sedang membius jutaan bahkan milyaran umat manusia. Jangan sampai generasi yang akan menjadi generasi penerus khilafah di muka bumi ini justru menjadi generasi yang merugi karena keengganan kita dalam mendidik mereka dan memberikan pemahaman tentang efek negatif 
jejering sosial sehingga mereka terperosok dan menjadi korban kejahatan dunia maya.

Menurut Ghufron \& Risnawita, (2011) salah satu dampak negatif yang ditimbulkan jejaring sosial berdasarkan teori diatas adalah prokrastinasi atau penundaan pekerjaan yang diakibatkan oleh banyaknya waktu yang di habiskan untuk situs jejaring sosial yang merupakan tempat mencari kesenangan dan hiburan sehingga dapat berdampak bagi kehidupan mereka, baik dari segi minat belajar, hasil, bersosialisasi dengan lingkungan, kepekaan sosial maupun perilakunya.

Ferrari (Ghufron \& Risnawita, 2010) mengatakan bahwa sebagai suatu perilaku prokrastinasi dapat termanifestasikan dalam indikator tertentu yang dapat diukur dan diamati berupa: 1) Penundaan untuk memulai maupun menyelesaikan, 2) Keterlambatan dalam mengerjakan tugas, 3) Kesenjangan waktu antara rencana dan kinerja actual, 4) Melakukan aktivitas lain yang lebih menyenangkan daripada mengerjakan tugas yang harus dikerjakan.

Guilford (Martina, 2014), mengelompokkan kemampuan berpikir ke dalam dua kelompok utama, yaitu; kemampuan memori dan kemampuan berpikir. Kemampuan berpikir dibedakan pula ke dalam tiga kategori, yaitu; kognitif, produktif, dan evaluatif. Kemampuan produktif terdiri dari dua jenis yaitu; konvergen dan divergen. Berpikir konvergen mengarah kepada suatu jawaban konvensional atau yang ditentukan. Sebaliknya, berpikir divergen bergerak ke berbagai arah, tidak terhadap jawaban yang diberikan. Berpikir konvergen fokus pada satu solusi yang benar, sedangkan berpikir divergen menghasilkan solusi yang bervariasi.

Selanjutnya Sitompul (Martina, 2014) mngemukakan bahwa cara berpikir kreatif adalah cara berpikir divergen atau kombinasi dua wajah dalam berpikir yaitu hakim (analitis, rasional dan logis) dan pemimpi (imajinatif, impulsif dan intuitif). Di sekolah biasanya anak hanya dilatih untuk berpikir "konvergen", yaitu untuk dapat menemukan satu jawaban terhadap suatu persoalan, atau pemikir logis. Anak kurang dirangsang untuk berpikir "divergen" atau berpikir kreatif, yaitu mampu untuk menemukan macam-macam kemungkinan jawaban terhadap suatu persoalan, jadi tidak hanya satu. Dengan berpikir divergen/ kreatif ini cakrawala pemikiran si anak seakan-akan dibentangkan, sehingga terbuka kemungkinan baginya kemungkinan-kemungkinan yang tidak pernah di lihat atau dialaminya sebelumnya. Selanjutnya, Menurut Ormroad (2008), pemikiran divergen adalah proses mengembangkan secara mental suatu ide tunggal ke berbagai arah.

Dari pendapat beberapa ahli, kemampuan berpikir divergen adalah proses berpikir yang berorientasi pada penemuan jawaban atau alternative yang banyak, dimana otak dibiarkan bergerak ke berbagai arah untuk mencapai ideide yang nantinya akan kita tampung. Seseorang dikatakan berpikir divergen dalam memecahkan masalah jika memenuhi empat kriteria, yaitu: kelancaran berpikir, keluwesan, originalitas, dan elaborasi.

Menurut Guildford (Martina, 2014) mengemukakan bahwa kemampuan berpikir divergen lebih terpusat pada produksi ide dan beranggapan bahwa semakin banyak ide yang bisa dihasilkan seseorang, semakin besar pula kesempatannya untuk memilih salah satu ide yang paling berguna. Sehingga dalam penelitiannya tentang intelligence, Guildford menggambarkan berpikir divergen sebagai suatu sifat yang didasari oleh empat faktor yaitu fluency, flexbility, originality, dan elaboration

Berdasarkan pemaparan di atas, maka dapat diasumsikan bahwa kecerdasan spiritual dan kecerdasan emosional merupakan dua variabel yang dapat mempengaruhi dampak negatif jejaring sosial dan kemampuan berpikir divergen sehingga dapat juga mempengaruhi hasil belajar matematika siswa. Dengan demikian dapat disimpulkan bahwa faktor-faktor yang bisa berpengaruh terhadap rendahnya hasil belajar matematika siswa adalah kecerdasan spiritual dan kecerdasan emosional melalui dampak negatif jejaring sosial dan kemampuan berpikir divergen. Oleh karena itu penulis tertarik untuk melakukan penelitian mengenai pengaruh kecerdasan spiritual, kecerdasan emosional, dampak negatif jejaring sosial dan kemampuan berpikir divergen terhadap hasil belajar matematika siswa kelas X SMA Negeri SeKecamatan Bontotiro Kabupaten Bulukumba.

Berdasarkan latar belakang yang telah dijelaskan di atas, dirumuskan masalah sebagai berikut: (1) Bagaimanakah gambaran kecerdasan spiritual, kecerdasan emosional, dampak negatif jejaring sosial, kemampuan berpikir divergen dan hasil belajar siswa kelas X SMA Negeri SeKecamatan Bontotiro Kabupaten Bulukumba? 
(2) Seberapa besar pengaruh kecerdasan spiritual terhadap hasil belajar matematika baik secara langsung maupun tidak langsung melalui dampak negatif jejaring sosial dan kemampuan berpikir divergen siswa kelas X SMA Negeri SeKecamatan Bontotiro Kabupaten Bulukumba? (3) Seberapa besar pengaruh kecerdasan emosional terhadap hasil belajar matematika baik secara langsung maupun tidak langsung melalui dampak negatif jejaring sosial dan kemampuan berpikir divergen siswa kelas X SMA Negeri SeKecamatan Bontotiro Kabupaten Bulukumba?.

Berikut ini adalah hipotesis yang digunakan dalam penelitian ini, adalah sebagai berikut: (1) Kecerdasan emosional bepengaruh positif terhadap hasil belajar matematika baik secara langsung maupun tidak langsung melalui kemampuan berpikir divergen dan melalui dampak negatif jejaring sosial siswa kelas $\mathrm{X}$ SMA Negeri Se-Kecamatan Bontotiro Kabupaten Bulukumba. (2) Kecerdasan spiritual bepengaruh positif terhadap hasil belajar matematika baik secara langsung maupun tidak langsung melalui kemampuan berpikir divergen dan melalui dampak negatif jejaring sosial siswa kelas X SMA Negeri Se-Kecamatan Bontotiro Kabupaten Bulukumba.(3) Ada hubungan antara kecerdasan spiritual dan kecerdasan emosional terhadap hasil belajar matematika siswa kelas X SMA Negeri Se-Kecamatan Bontotiro Kabupaten Bulukumba

Adapun diagram keterkaitan pengaruh antara variabel dalam rangka perumusan hipotesis di atas adalah sebagai berikut:

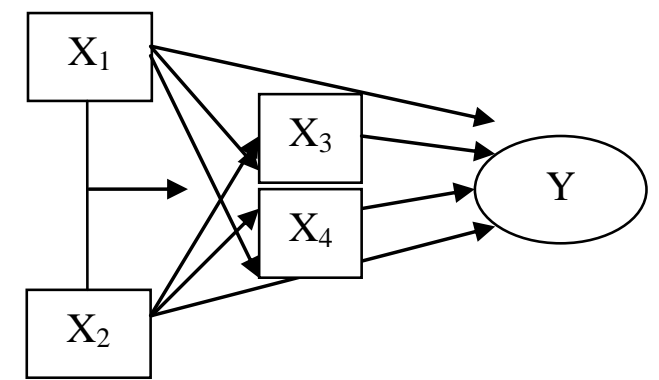

Gambar 2.1 Diagram Hipotik

Keterangan: Hubungan Kausal, $\mathrm{X}_{1}:$ Kecerdasan spiritual, $\mathrm{X}_{2}$ : Kecerdasan emosional, $\mathrm{X}_{3}$ : Dampak negatif jejaring social, $\mathrm{X}_{4}$ : Kemampuan berpikir divergen, $\mathrm{Y}$ : Hasil belajar matematika

\section{METODE}

Penelitian ini termasuk penelitian ex-post facto yang bersifat korelasional. Penelitian expost facto disini dirancang untuk mejelaskan adanya pengaruh beberapa variabel yang telah ditetapkan. Penelitian ini menguji hipotesis yang telah dirumuskan sebelumnya yakni kecerdasan spiritual, kecerdasan emosional, dampak negatif jejaring sosial, kemampuan berpikir divergen terhadap hasil belajar matematika.

Variabel yang diselidiki dalam penelitian ini terbagi dalam tiga jenis, yaitu variabel eksogen, variabel intervening dan variabel endogen. Variabel eksogen adalah variabel independen yang mempengaruhi variabel dependen. Dalam penelitian ini yang bertindak sebagai variabel eksogen adalah kecerdasan spiritual $\left(\mathrm{X}_{1}\right)$ dan kecerdasan emosional $\left(\mathrm{X}_{2}\right)$. Variabel endogen adalah variabel dependen yang dipengaruhi oleh variabel independen (eksogen) dan dalam penelitian ini yang bertindak sebagai variabel endogen adalah hasil belajar matematika (Y). Variabel intervening adalah variabel yang bertindak sebagai variabel eksogen sekaligus variabel endogen dan merupakan variabel yang menjembatani antara variabel eksogen dengan variabel endogen. Dalam penelitian ini yang bertindak sebagai variabel intervening adalah dampak negatif penggunaan jejaring sosial $\left(X_{3}\right)$ dan kemampuan berpikir divergen $\left(\mathrm{X}_{4}\right)$.

Berdasarkan kajian pustaka diatas, diperoleh definisi operasional tiap variabel sebagai berikut:

1. Kecerdasan spiritual $\left(\mathrm{X}_{1}\right)$ adalah kecerdasan spiritual adalah kemampuan memberi makna ibadah terhadap setiap perilaku dan kegiatan melalui langkah-langkah dan pemikiran yang bersifat fitrah, menuju manusia yang seutuhnya dan memiliki pola pemikiran luas, serta berprinsip hanya karena Allah. Adapun indikator kecerdasan spiritual menurut Ginanjar (2001) adalah menyangkut aspek penerapan suara hati yang suci (asmaul husna), dengan alasan seperti yang telah diuraikan pada kajian teori di atas bahwa suara hati adalah kunci spiritual karena ia adalah pancaran sifat-sifat Ilahi.

2. Kecerdasan emosional $\left(\mathrm{X}_{2}\right)$ adalah kemampuan sesesorang untuk mengenali emosi diri, pengaturan diri, memotivasi diri sendiri, mengenali emosi orang lain (empati) dan kemampuan untuk membina hubungan (keterampilan sosial) dengan 
orang lain. Adapun indikator kecerdasan emosional menurut Salovey (Goleman, 2007) yaitu sebagai berikut:
a. Mengenali emosi diri
b. Mengelola emosi
c. Memotivasi diri sendiri
d. Mengenali emosi orang lain (empati)
e. Membina hubungan

3. Dampak negatif jejaring sosial $\left(\mathrm{X}_{3}\right)$. Jejaring sosial adalah struktur sosial yang terdiri dari elemen-elemen individual atau komunitas yang diikat oleh sebuah relasi untuk saling terhubung dengan cepat antara satu domain komunitas dengan komunitas lainnya. Dampak negatif jejaring sosial yang dimaksud dalam penelitian ini adalah prokrastinasi atau penundaan pekerjaan yang diakibatkan oleh banyaknya waktu yang di habiskan untuk situs jejaring sosial yang merupakan tempat mencari kesenangan dan hiburan sehingga dapat berdampak bagi kehidupan mereka, baik dari segi minat belajar, hasil, bersosialisasi dengan lingkungan, kepekaan sosial maupun perilakunya. Adapun indikator dampak negatif penggunaan jejaring sosial menurut Ferrari (Ghufron \& Risnawita, 2011) yaitu:

a. Penundaan untuk memulai maupun menyelesaikan

b. Keterlambatan dalam mengerjakan tugas.

c. Kesenjangan waktu antara rencana dan kinerja aktual

d. Kecenderungan untuk melakukan aktivitas lain yang dipandang dapat mendatangkan hiburan dan kesenangan.

4. Kemampuan berpikir divergen $\left(\mathrm{X}_{4}\right)$ adalah proses berpikir yang berorientasi pada penemuan jawaban atau alternatif yang banyak, dimana otak dibiarkan bergerak ke berbagai arah untuk mencapai ide-ide yang nantinya akan kita tampung. Adapun indikator kemampuan berpikir divergen yaitu:

a. fluency (kelancaran) adalah kemampuan membangun banyak ide. Semakin banyak ide yang didapat berpeluang untuk mendapatkan ide yang bagus.

b. flexibility (keluwesan) adalah kemampuan membangun ide yang beragam, yaitu kemampuan untuk mencoba berbagai pendekatan dalam memecahkan masalah. c. originality (keaslian) adalah kemampuan untuk menghasilkan ide-ide yang luar biasa yang tidak umum.

d. elaboration (elaborasi) adalah kemampuan untuk menghasilkan sebuah karya baru atau solusi-solusi yang khusus atau unik dan berbeda.

5. Hasil belajar matematika (Y) adalah tingkat pencapaian atau penguasaan siswa terhadap materi pelajaran matematika yang telah diajarkan dalam kurun waktu tertentu sebagai hasil kegiatan belajar yang dinyatakan dengan nilai ujian tengah semester genap tahun pelajaran 2014/2015. Semakin tinggi nilainya, maka semakin tinggi prestasi belajar matematikanya.

6. Pengaruh langsung (Direct Effect) adalah pengaruh satu variabel penyebab terhadap variabel akibat tanpa melalui variabel lain.

7. Pengaruh tidak langsung (Indirect effect) adalah pengaruh satu variabel penyebab terhadap variabel akibat yang terjadi melalui satu atau beberapa variabel lain yang dikonsepsikan sebagai variabel antara (intervening).

Populasi dalam penelitian ini adalah seluruh siswa kelas X SMA Negeri di Kecamatan Bontotiro Kabupaten Bulukumba tahun pelajaran 2014/2015. Berdasarkan data yang diperoleh dari Dinas Pendidikan Kabupaten Bulukumba Kecamatan Bontotiro, diperoleh jumlah SMA Negeri yang ada di Kecamatan Bontotiro Kabupatean Bulukumba sebanyak 3 sekolah dengan jumlah siswa seluruhnya yaitu sebanyak 765

Teknik pengambilan sampel yang digunakan untuk memperoleh sampel acak dan merepresentasikan karakteristik populasi adalah menggunakan Teknik proporsional stratified ramdom sampling. Teknik proporsional stratified random sampling adalah pengambilan sampel dari anggota populasi secara acak dan berstrata secara proporsional, dilakukan sampling ini apabila anggota populasinya heterogen (tidak sejenis). Proportional stratified random sampling ini dilakukan dengan cara membuat lapisanlapisan (strata), kemudian dari setiap lapisan diambil sejumlah subjek secara acak. Jumlah subjek dari setiap lapisan (strata) adalah sampel penelitian, (Sugiyono, 2013).

Penentuan besar sampel yang dilakukan dengan mengambil jumlah sebanyak $40 \%$ dari populasi yang ada. Dari jumlah populasi yang 
diambil sebagai sampel penelitian sebanyak 541, yang terdiri dari SMA Negeri 4 Bulukumba sebanyak 282 siswa dan SMA Negeri 11 Bulukumba sebanyak 259 siswa. Banyaknya siswa yang menjadi subjek penelitian ini adalah 40\% dari 541 siswa yaitu sebanyak 216 siswa. Selanjutnya, masing-masing sampel untuk setiap sekolah diproporsionalkan sesuai dengan jumlah populasi yang ada dalam sekolah tersebut, maka jumlah sampel untuk SMA Negeri 4 Bulukumba sebanyak 113 siswa dan SMA Negeri 11 Bulukumba sebanyak 103 siswa.

Peneliti menggunakan instrument yang diberikan kepada setiap sampel penelitian untuk memperoleh data yang diperlukan dari setiap variabel. Adapun instrumen penelitian yang dipergunakan dalam penelitian ini adalah angket dan tes. Angket digunakan untuk mengumpulkan data mengenai variabel kecerdasan spiritual, kecerdasan emosional, dan dampak negatif jejaring sosial. Pada penelitian ini akan digunakan Skala Likert dengan memodifikasi menghilangkan jawaban tengah atau dengan jawaban skala Likert 4-titik. Alasan memilih skala likert dengan menghilangkan jawaban tengah atau dengan 4 titik adalah untuk mengatasi kecenderungan responden memilih jawaban aman yaitu jawaban tidak punya pendapat utamanya bagi responden yang raguragu sebagaimana dikatakan Azwar (2013: 47) bila pilihan tengah disediakan maka responden akan cenderung memilihnya sehingga menyebabkan data mengenai perbedaan di antara responden akan menjadi kurang informatif.

Skala Likert 4-titik diambil sebagai patokan pada semua butir pernyataan dalam skala penilaian. Oleh karena itu, dalam Skala Likert 4-titik, alasan responden akan diberikan pernyataan dengan pilihan penilaian diri responden antara interval 1 samapai 4 . Angka 1 sampai 4 ini merupakan skor nilai dari penilaian responden yang memiliki arti. Skala kecerdasan spiritual dan skala kecerdasan emosional pernyataan positif skor 4 bila responden menjawab sangat sesuai (SS), skor 3 bila responden menjawab sesuai (S), skor 2 bila responden menjawab tidak sesuai (TS), dan skor 1 bila responden menjawab sangat tidak sesuai (STS). Pernyataan negatif skor 1 bila responden menjawab sangat sesuai (SS), skor 2 bila responden menjawab sesuai (S), skor 3 jika responden menjawab tidak sesuai (TS) dan skor 4 jika responden menjawab sangat tidak sesuai
(STS). Skala dampak negatif jejaring sosial pernyataan negatif skor 4 bila responden menjawab sangat sesuai (SS), skor 3 bila responden menjawab sesuai (S), skor 2 bila responden menjawab tidak sesuai (TS), dan skor 1 bila responden menjawab sangat tidak sesuai (STS). Pernyataan positif skor 1 bila responden menjawab sangat sesuai (SS), skor 2 bila responden menjawab sesuai (S), skor 3 jika responden menjawab tidak sesuai (TS) dan skor 4 jika responden menjawab sangat tidak sesuai (STS)

Untuk mengukur variabel hasil belajar matematika siswa, metode pengumpulan data yang digunakan adalah dokumentasi. Metode dokumentasi adalah salah satu metode pengumpulan data dengan menggunakan bahanbahan yang sudah ada atau tersedia dalam suatu arsip tertentu di lingkungan penelitian. Sekumpulan data tersebut berisikan tentang aspek-aspek atau atribut tertentu yang akan digunakan sebagai bahan kajian pokok dalam penelitian.

Pemberian skor berkaitan dengan penskalaan, yang mana penskalaan merupakan proses penentuan letak kategori respon pada suatu kontinum psikologis. Selain itu proses penskalaan memusatkan perhatian pada karakteristik angka-angka yang merupakan nilai skala. Skor pada skala psikologis yang ditentukan melalui prosedur penskalaan akan menghasilkan angka-angka pada level pengukuran (Azwar, 2013:148).

$$
\text { Skor terendah } \leq X<\mu-2,5(\sigma)
$$

Kategori sangat rendah

Kategori rendah

$$
\mu-2,5(\sigma) \leq X<\mu-1,5(\sigma)
$$

Kategori sedang

$$
\mu-1,5(\sigma) \leq X<\mu-0,5(\sigma)
$$

Kategori tinggi

$$
\mu-0,5(\sigma) \leq X<\mu+0,5(\sigma)
$$

$$
\mu+0,5(\sigma) \leq X \leq \text { skor terting } i
$$

Kategori sangat tinggi

Dimana $\mu=$ skor terendah $\times 3$

$\sigma=\frac{\text { skor tertinggi-skor terendah }}{6}$

Adapun langkah-langkah yang ditempuh untuk melakukan pengumpulan data dalam kegiatan penelitian ini adalah:

1. Melakukan eksplorasi kepustakaan yang mendukung variabel sebagai indikator pengumpul informasi. 
2. Melakukan pensahihan (validasi instrumen) terhadap hasil eksplorasi kepustakaan yang dilakukan, sesuai dengan teknik validasi yang digunakan.

3. Melakukan ujicoba pada instrumen penelitian untuk mengukur validitas dan reliabilitas

4. Melakukan pengumpulan data berdasarkan instrumen yang telah diperoleh, diterapkan pada sampel yang dipilih dalam kegiatan penelitian ini

5. Melakukan analisis pada data yang diperoleh

Menganalisis data hasil penelitian menggunakan teknik statistika deskriptif dan infrensial. Statistika deskriptif dimaksudkan untuk memberikan gambaran alami data sampel dari variabel penelitian, yaitu berupa mean, median, modus, standar deviasi, variansi, skewness, kurtosis, range, minimum, maksimum, dan analisis persentase. Statistika inferensial dimaksudkan untuk analisis dan validasi model yang diusulkan serta pengujian hipotesis. Oleh karena itu digunakan teknik analisis SEM (Structural Equation Modelling) dengan menggunakan paket program AMOS (Analysis of Moment Structure) SPSS versi 20 dan tes sobel online.

\section{HASIL PENELITIAN}

\section{Hasil}

1. Karakteristik distribusi skor responden masing-masing variabel

a. Variabel kecerdasan spiritual

Tabel 4.1 Distribusi Skor Kecerdasan Spiritual Siswa Kelas X SMA Negeri Se-Kecamatan Bontotiro Kabupaten Bulukumba

\begin{tabular}{ccccc}
\hline \hline No & Skor & Frekuensi & Persentase (\%) & Kategori \\
\hline 1 & $32 \leq \mathrm{X}_{1}<56$ & 0 & 0 & Sangat Rendah \\
2 & $56 \leq \mathrm{X}_{1}<72$ & 0 & 0 & Rendah \\
3 & $72 \leq \mathrm{X}_{1}<88$ & 5 & 2,8 & Sedang \\
4 & $88 \leq \mathrm{X}_{1}<102$ & 137 & 78,3 & Tinggi \\
5 & $102 \leq \mathrm{X}_{1} \leq 128$ & 33 & 18,9 & Sangat Tinggi \\
\hline & Jumlah & 175 & 100 & \\
\hline \hline Mean & Std. Deviasi & Variansi & Minimum & Maksimum \\
\hline 100,87 & 8,061 & 64,977 & 83 & 120 \\
\hline \hline
\end{tabular}

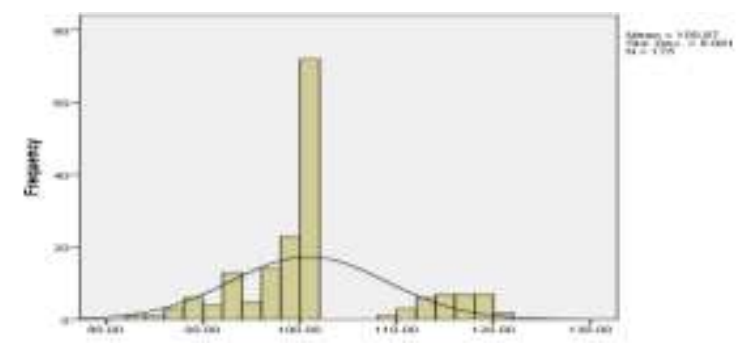

\section{b. Variabel kecerdasan emosional}

Tabel 4.2 Distribusi Skor Kecerdasan Emosional Siswa Kelas X SMA Negeri Se-Kecamatan Bontotiro Kabupaten Bulukumba

\begin{tabular}{ccccc}
\hline \hline No & Skor & Frekuensi & Persentase $(\%)$ & Kategori \\
\hline 1 & $27 \leq \mathrm{X}_{2}<47$ & 0 & 0 & Sangat Rendah \\
2 & $47 \leq \mathrm{X}_{2}<61$ & 0 & 0 & Rendah \\
3 & $61 \leq \mathrm{X}_{2}<74$ & 8 & 4,6 & Sedang
\end{tabular}




\begin{tabular}{rcccc}
4 & $74 \leq \mathrm{X}_{2}<88$ & 132 & 75,4 & Tinggi \\
5 & $88 \leq \mathrm{X}_{2} \leq 108$ & 35 & 20 & Sangat Tinggi \\
\hline & Jumlah & 175 & 100 & \\
\hline \hline Mean & Std. Deviasi & Variansi & Minimum & Maksimum \\
\hline 85,54 & 6,917 & 47,848 & 67 & 103 \\
\hline \hline
\end{tabular}

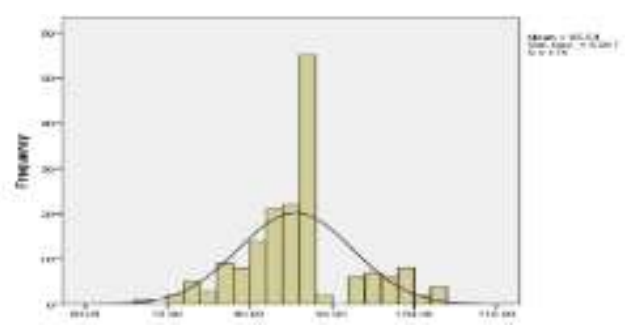

\section{c. Variabel dampak negatif jejaring sosial}

Tabel 4.3 Distribusi Skor Dampak Negatif Jejaring Sosial Siswa Kelas X SMA Negeri SeKecamatan Bontotiro Kabupaten Bulukumba

\begin{tabular}{ccccc}
\hline \hline No & Skor & Frekuensi & Persentase (\%) & Kategori \\
\hline 1 & $24 \leq \mathrm{X}_{3}<42$ & 30 & 17,1 & Sangat Rendah \\
2 & $42 \leq \mathrm{X}_{3}<54$ & 108 & 61,8 & Rendah \\
3 & $54 \leq \mathrm{X}_{3}<66$ & 37 & 21,1 & Sedang \\
4 & $66 \leq \mathrm{X}_{3}<78$ & 0 & 0 & Tinggi \\
5 & $78 \leq \mathrm{X}_{3} \leq 96$ & 0 & 0 & Sangat Tinggi \\
\hline & Jumlah & 175 & 100 & \\
\hline \hline Mean & Std. Deviasi & Variansi & Minimum & Maksimum \\
\hline 50,07 & 7,623 & 58,104 & 34 & 65 \\
\hline \hline
\end{tabular}

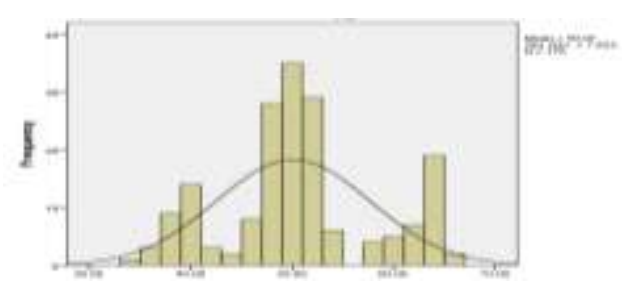

\section{d. Variabel kemampuan berpikir divergen}

Tabel 4.4 Distribusi Skor Kemampuan Berpikir Divergen Siswa Kelas X SMA Negeri SeKecamatan Bontotiro Kabupaten Bulukumba

\begin{tabular}{ccccc}
\hline \hline No & Skor & Frekuensi & Persentase $(\%)$ & Kategori \\
\hline 1 & $0 \leq \mathrm{X}_{4}<40$ & 0 & 0 & Sangat Rendah \\
2 & $40 \leq \mathrm{X}_{4}<60$ & 0 & 0 & Rendah \\
3 & $60 \leq \mathrm{X}_{4}<75$ & 62 & 35,4 & Sedang \\
4 & $75 \leq \mathrm{X}_{4}<90$ & 110 & 62,9 & Tinggi \\
5 & $90 \leq \mathrm{X}_{4} \leq 100$ & 3 & 1,7 & Sangat Tinggi \\
\hline & Jumlah & 175 & 100 & \\
\hline \hline Mean & Std. Deviasi & Variansi & Minimum & Maksimum \\
\hline 77,08 & 6,329 & 40,051 & 60 & 90 \\
\hline \hline
\end{tabular}

Histogram Dampak Negatif Jejaring Sosial, (Sumber: lampiran 6) 


\section{e. Variabel hasil belajar}

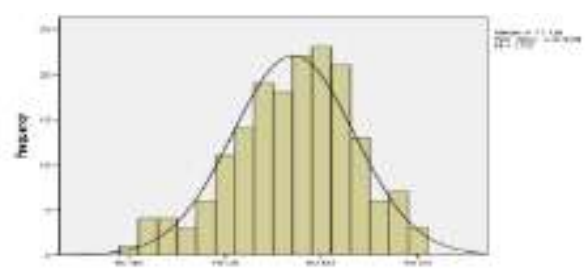

Tabel 4.5 Distribusi Skor Hasil Belajar Matematika Siswa Kelas X SMA Negeri Se-Kecamatan Bontotiro Kabupaten Bulukumba

\begin{tabular}{ccccc}
\hline \hline No & Skor & Frekuensi & Persentase $(\%)$ & Kategori \\
\hline 1 & $0 \leq \mathrm{HB}<40$ & 0 & 0 & Sangat Rendah \\
2 & $40 \leq \mathrm{HB}<60$ & 0 & 0 & Rendah \\
3 & $60 \leq \mathrm{HB}<75$ & 20 & 11,4 & Sedang \\
4 & $75 \leq \mathrm{HB}<90$ & 148 & 84,6 & Tinggi \\
5 & $90 \leq \mathrm{HB} \leq 100$ & 7 & 4 & Sangat Tinggi \\
\hline & Jumlah & 175 & 100 & \\
\hline \hline Mean & Std. Deviasi & Variansi & Minimum & Maksimum \\
\hline 82,22 & 5,267 & 27,737 & 70 & 91 \\
\hline \hline
\end{tabular}

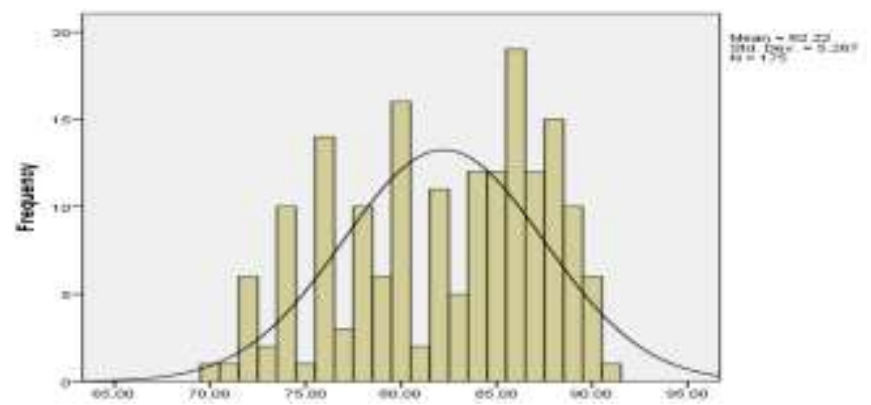

Adapun model SEM berdasarkan kajian teori yang akan diuji adalah sebagai berikut ini:

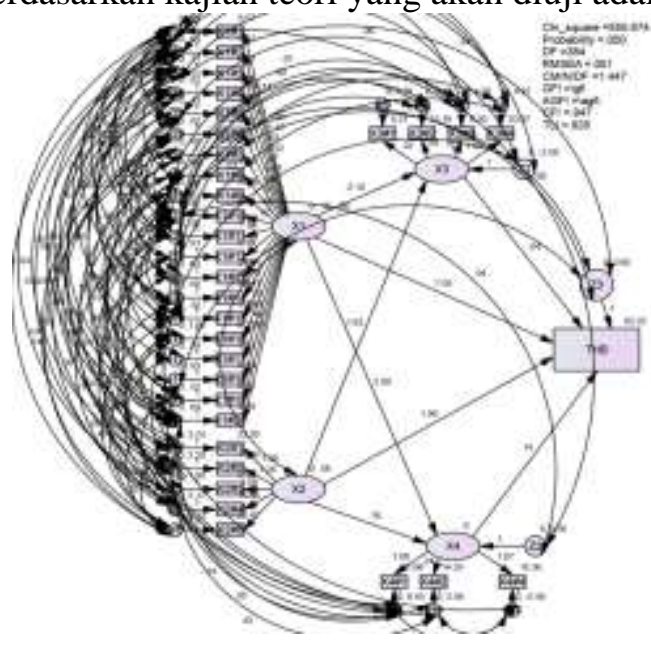


Tabel 4.6 Regression Weight untuk Model

\begin{tabular}{|c|c|c|c|c|c|c|c|}
\hline & & & $\begin{array}{l}\text { Standa } \\
r \\
\text { Regresi } \\
\text { on } \\
\text { Weight } \\
\end{array}$ & Estimate & S.E. & C.R. & $\mathrm{P}$ \\
\hline DNJS & $<-$ & Kec_Spiritual & $-0,653$ & -5.105 & 0,696 & -7.330 & 0,001 \\
\hline DNJS & $<--$ & Kec_Emosional & $-0,389$ & -1.618 & 0,175 & -9.237 & 0,001 \\
\hline Berfikir_Divergen & $<--$ & Kec_Spiritual & 0,399 & 2.981 & 0,581 & 5.129 & 0,001 \\
\hline Berfikir_Divergen & $<-$ & Kec_Emosional & 0,191 & 0,760 & 0,137 & 5.527 & 0,001 \\
\hline $\mathrm{HB}$ & $<-$ & Kec_Spiritual & 0,534 & 7.048 & 1.035 & 6.807 & 0,001 \\
\hline $\mathrm{HB}$ & $<-$ & Kec_Emosional & 0,279 & 1.958 & 0,233 & 8.418 & 0,001 \\
\hline $\mathrm{HB}$ & $<-$ & Berfikir_Divergen & 0,081 & 0,143 & 0,070 & 2.052 & 0,040 \\
\hline $\mathrm{HB}$ & $<-$ & DNJS & $-0,023$ & $-0,038$ & 0,051 & $-0,745$ & 0,456 \\
\hline
\end{tabular}

Tabel 4.7 Squared Multiple Correlation

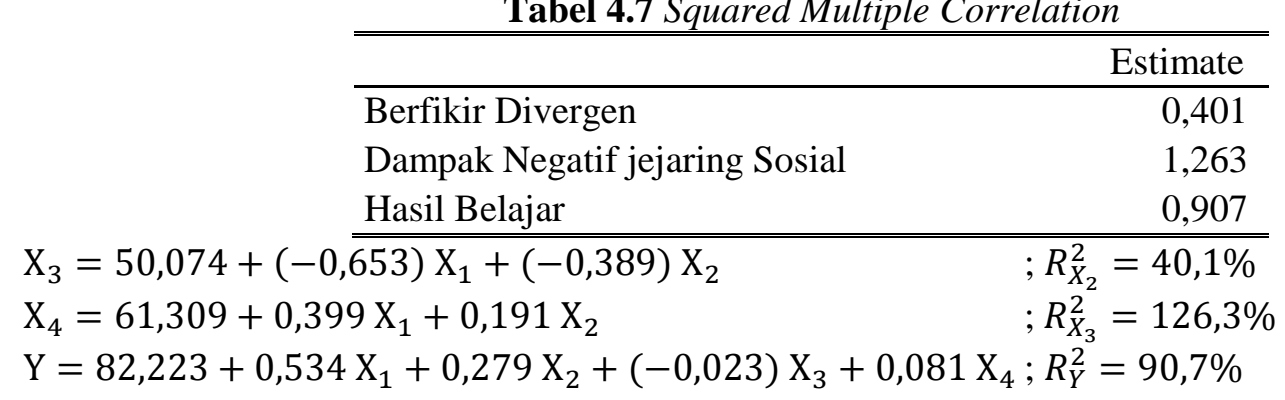

Keterangan:

$\mathrm{X}_{1} \quad=$ Kecerdasan spiritual

$\mathrm{X}_{2} \quad=$ Kecerdasan emosional

$\mathrm{X}_{3} \quad=$ Dampak negatif jejaring sosial

$\mathrm{X}_{4} \quad=$ Kemampuan berpikir divergen

$\mathrm{Y} \quad=$ Hasil Belajar Matematika

Tabel. 4.8 Matriks Korelasi Antar Variabel

\begin{tabular}{lrrrrr}
\hline \hline & $\begin{array}{c}\text { Kec. } \\
\text { Emosional }\end{array}$ & $\begin{array}{c}\text { Kec. } \\
\text { Spiritual }\end{array}$ & $\begin{array}{c}\text { Berpikir } \\
\text { Divergen }\end{array}$ & DNJS & $\begin{array}{c}\text { Hasil } \\
\text { Belajar }\end{array}$ \\
\hline Kec.emosional & 1.000 & & & & \\
Kec. spiritual & 1.343 & 1.000 & & & \\
Berpikir Divergen & .696 & .628 & 1.000 & & \\
DNJS & -1.266 & -1.177 & -.682 & 1.000 & \\
Hasil_Belajar & 1.083 & .989 & .623 & -1.062 & 1.000 \\
\hline
\end{tabular}

Tabel 4.9 Sumbangan Efektif Variabel X terhadap Variabel Y

\begin{tabular}{|c|c|c|c|c|c|}
\hline No & Pengaruh $\mathrm{X}$ terhadap $\mathrm{Y}$ & $\mathrm{L}$ & $\begin{array}{c}\text { TL } \\
\text { Melalui } \mathrm{X}_{3}\end{array}$ & $\begin{array}{c}\mathrm{TL} \\
\text { Melalui } \\
\mathrm{X}_{4}\end{array}$ & Total \\
\hline 1 & Peng & Hen & rhadap Y & & \\
\hline
\end{tabular}




\begin{tabular}{cccccc}
\hline \hline & $\mathrm{X}_{1}$ & 0,528 & - & - & 0,528 \\
& $\mathrm{X}_{1}$ melalui $_{3}$ & - & 0,019 & - & 0,019 \\
& $\mathrm{X}_{1}$ melalui $\mathrm{X}_{4}$ & - & & 0,013 & 0,013 \\
& $\mathrm{X}_{2}$ & 0,302 & - & - & 0,302 \\
& $\mathrm{X}_{2}$ melalui $_{3}$ & - & 0,012 & - & 0,012 \\
& $\mathrm{X}_{2}$ melalui $_{4}$ & - & - & 0,007 & 0,007 \\
\hline \multicolumn{5}{c}{} \\
\hline
\end{tabular}

\section{SIMPULAN DAN SARAN}

Berdasarkan hasil analisis data penelitian pada bab sebelumnya, beberapa kesimpulan dari hasil penelitian ini adalah:

1. Rata-rata siswa kelas X SMA Negeri SeKecamatan Bontotiro Kabupaten Bulukumba memiliki kecerdasan spiritual berada dalam kategori tinggi, kecerdasan emosional berada dalam kategori tinggi, dampak negatif jejaring sosial berada dalam kategori rendah, kemampuan berpikir divergen berada dalam kategori tinggi, dan hasil belajar matematika berada pada kategori tinggi.

2. Secara langsung kecerdasan spiritual $\left(X_{1}\right)$ berpengaruh positif yang signifikan terhadap hasil belajar matematika siswa kelas X SMA Negeri Se-Kecamatan Bontotiro Kabupaten Bulukumba (Y) dengan besarnya pengaruh langsung adalah 0,528 atau $52,8 \%$, koefisien jalur 0,534 yang signifikan dengan nilai $\mathrm{p}=$ $0,001<0,05$ yang signifikan. Secara tidak langsung kecerdasan spiritual berpengaruh positif yang tidak signifikan terhadap hasil belajar matematika siswa (Y) melalui dampak negatif jejaring sosial $\left(\mathrm{X}_{3}\right)$ dengan besarnya pengaruh tidak langsung adalah 0,019 atau $1,9 \%$, koefisien jalur yaitu 0,015 yang tidak signifikan dengan nilai $\mathrm{p}$ $=0,229>0,05$. Secara tidak langsung kecerdasan spiritual berpengaruh positif yang signifikan terhadap hasil belajar matematika siswa kelas (Y) melalui kemampuan berpikir divergen $\left(\mathrm{X}_{4}\right)$ dengan besarnya pengaruh tidak langsung adalah 0,013 atau $1,3 \%$ dengan koefisien jalur yaitu 0,032 yang signifikan dengan nilai $\mathrm{p}$ $=0,029<0,05$.
3. Secara langsung kecerdasan emosional $\left(\mathrm{X}_{2}\right)$ berpengaruh positif yang signifikan terhadap hasil belajar matematika siswa kelas X SMA Negeri Se-Kecamatan Bontotiro Kabupaten Bulukumba (Y) dengan besarnya pengaruh langsung adalah 0,302 atau 30,2\% dengan koefisien jalur yaitu 0,279 yang signifikan dengan nilai $\mathrm{p}=0,001<0,05$. Secara tidak langsung kecerdasan emosional $\left(\mathrm{X}_{2}\right)$ berpengaruh positif yang tidak signifikan terhadap hasil belajar matematika siswa (Y) melalui dampak negatif jejaring sosial $\left(\mathrm{X}_{3}\right)$ dengan besarnya pengaruh tidak langsung adalah 0,012 atau 1,2\% dengan koefisien jalur yaitu 0,009 yang tidak signifikan dengan nilai $\mathrm{p}=0,228>0,05$. Secara tidak langsung kecerdasan emosional $\left(\mathrm{X}_{2}\right)$ berpengaruh positif yang signifikan terhadap hasil belajar matematika siswa $(\mathrm{Y})$ melalui kemampuan berpikir divergen $\left(\mathrm{X}_{4}\right)$ dengan besarnya pengaruh tidak langsung adalah 0,007 atau $0,7 \%$ dengan koefisien jalur yaitu 0,015 yang signifikan dengan nilai $\mathrm{p}=0,028<$ 0,05 .

\section{DAFTAR RUJUKAN}

Agustian, Ary Ginanjar. 2007. ESQ Power. Jakarta: Penerbit Arga.

Agustian, Ary Ginanjar. 2001. Rahasia Sukses Membangun Kecerdasan Spiritual ESQ (Emotional Spiritual Quotient) The ESQ way 165. Jilid 1. Jakarta: Penerbit Arga

Azwar, Syaifuddin. 2013. Skala Pengukuran Psikologi Pendidikan. Yogyakarta: Pustaka Belajar.

Briyan Anugerah Pekerti. 2013. Pengaruh Jejaring Sosial Terhadap Kelakuan 
Seseorang. On line di. http://jurnalilmiahtp. blogspot. com/2013/11/pengaruh-jejaring-sosialterhadap_11.html. Jurusan Kurikulum dan Teknologi Pendidikan Fakultas Ilmu Pendidikan, Universitas Negeri Semarang brian_davenger@ymail.com._Diakses tanggal 3 November 2014

Dea Anggraeni Utomo. 2013. Motif pengguna jejaring sosial Google+ di Indonesia. Jurnal e-komunikasi Volume I No 3. deaanggraenii@yahoo.com. program studi ilmu komunikasi Universitas kristen Petra, Surabaya. Diakses tanggal 3 November 2014

Ghufron \& Risnawita. 2011. Teori-teori Psikologi. Yogyakarta: Ar-Ruzz Media

Goleman, Daniel. 2007. Emotional Intellegence (Terjemahan). Jakarta: PT Gramedia Pustaka Utama

Harjani Hefni, 2008. The 7 Islamic Daily Habits. Jakarta: Percetakan IKADI

Lisda Rahmasari. 2012. Pengaruh Kecerdasan Intelektual, Kecerdasan Emosi dan Kecerdasan Spiritual Terhadap Kinerja Karyawan. Jurnal. Fakultas Ekonomi Universitas AKI. Diakses tanggal 3 November 2014.

Martina Ismayanti. 2014. Pengaruh Faktorfaktor Pembangun Kecemasan Belajar Matematika dan Efikasi Diri terhadap Hasil Belajar Matematika Melalui Kemampuan Berpikir Divergen pada Siswa Kelas VII SMP Negeri di Kota Makassar. Tesis. Tidak diterbitkan. Makassar: UniversitasNegeri Makassar.

Ormrod, Jeanne Ellis. 2008. Psikologi Pendidikan Jilid 2: Membantu Siswa Tumbuh dan Berkembang. Jakarta: Erlangga.

Sanerya, Hendrawan. 2009. Spiritual Management. Bandung: PT. Mizan Pustaka.

Sagala, Syaiful. 2011. Konsep dan Makna Pembelajaran. Bandung: Penerbit Alfabeta

Sawitri, Amalia. 2004. Hubungan Antara Kecerdasan Emosional dengan Hasil Belajar pada Siswa Kelas II SMU Lab School Jakarta Timur

Sugiyono. 2013. Merode Pelitian Kuantitatif Kualitatif dan $R \& D$. Bandung: Alfabeta 